\title{
Rapid RT-PCR Amplification from Limited Cell Numbers
}

\author{
S. Edmands, J. Kirk, A. Lee, and J. Radich \\ The Division of Experimental Pathology and Clinical Research, Fred Hutchinson Cancer Research Center, \\ Seattle, Washington 98104
}

We describe a rapid and efficient RTPCR method particularly suited to procedures involving limited cell and target gene copy numbers. Purified leukocytes and myeloid colonies derived from patients with chronic myelogenous leukemia (CML) in chronic phase were used for direct RT-PCR. Purified cells and colonies were lysed using a small quantity of DEPCtreated water containing RNasin as an RNA inhibitor. The untreated lysate was either used immediately for RT-PCR or frozen at $-70^{\circ} \mathrm{C}$ for later use. By this method we were able to consistently amplify bcr-abl transcripts from as few as 10 cells. No noticeable difference was observed between products amplified from fresh and frozen samples. hen working with cultured cells or very small cell numbers from patient samples, it is often difficult to perform reliable reverse transcriptase-polymerase chain reaction (RT-PCR) using standard RNA purification methods. ${ }^{(1)}$ The multiple manipulations and transfers required for this method, in combination with small initial target gene copy numbers, make it difficult to obtain sufficient RNA after purification for successful amplification. This is an even greater problem when it is necessary to amplify a control gene such as $\beta-2 \mathrm{mi}$ croglobulin to assess RNA integrity. In addition, the time and resources necessary for standard RNA extraction can be prohibitive when working with large numbers of samples. Shi et al. ${ }^{(2)}$ describe a rapid method for direct RT-PCR from whole blood that eliminates formal RNA extraction. Although fast, this method is not ideally suited to use with small cell numbers, as it does not avoid the problem of template loss that can accompany sample transfers during RNA purification. We describe a simplified method for RT-PCR amplification from cells that eliminates any loss of RNA and provides rapid and efficient amplification from small cell numbers.

\section{MATERIALS AND METHODS \\ Preparation of Total RNA from Cells}

To each reaction tube containing cell samples, $10 \mu \mathrm{l}$ of diethylpyrocarbonate (DEPC)-treated $\mathrm{H}_{2} \mathrm{O}$ (all DEPC-treated water was heat-inactivated after overnight incubation) containing 2-4 units of RNasin (0.2-0.4 U/ $\mu \mathrm{l}$ ) (Promega) was added, mixed in the pipette tip to assist in lysis, and incubated for $20 \mathrm{~min}$ on ice. The lysate was then either frozen at $-70^{\circ} \mathrm{C}$ or used directly as a template for the RT-PCR reaction as described below.

\section{Primers}

Oligonucleotide sequences for the $b c r-$ $a b l$ transcript are shown in Table 1 . Their relative positions are shown in Figure 1. The nested reaction yields either a 305or a 234-bp product depending on expression of bcr exon 3 (Fig. 1).

\section{RT-PCR}

To the $10 \mu$ l of lysate was added $40 \mu$ of the combined RT-PCR mixture given in final concentrations: 25 pmoles each of oligonucleotides CMLND and CMLNC, $50 \mathrm{~mm} \mathrm{KCl}, 10 \mathrm{~mm}$ Tris- $\mathrm{HCl}$ (pH 9.0), $0.1 \%$ Triton X-100, $200 \mu \mathrm{M}$ dNTPs, 1.5 $\mathrm{mM} \mathrm{MgCl}_{2}, 1.25$ units of Taq polymerase (AmpliTaq, Perkin-Elmer Cetus), 10 units of RNasin, 7.5 units of AMV-RT (Boehringer Mannheim), and DEPCtreated $\mathrm{H}_{2} \mathrm{O}$ to bring the final volume including sample to $50 \mu \mathrm{l}$. The reaction mixture was incubated for $30 \mathrm{~min}$ at $42^{\circ} \mathrm{C}$, brought up to $95^{\circ} \mathrm{C}$ for $5 \mathrm{~min}$, and amplified using 40 cycles of $94^{\circ} \mathrm{C}$ for 30 $\mathrm{sec}, 55^{\circ} \mathrm{C}$ for $1 \mathrm{~min}$, and $72^{\circ} \mathrm{C}$ for $1 \mathrm{~min}$ followed by a final elongation at $72^{\circ} \mathrm{C}$ for $7 \mathrm{~min}$ on an Omnigene thermocycler (Hybaid Ltd). For the second reaction, 5 $\mu l$ from the first amplification tube was transferred to a second reaction tube containing fresh PCR ingredients: 25 pmoles oligonucleotides CMLNA and CMLNB, $500 \mathrm{~mm} \mathrm{KCl,} 10 \mathrm{~mm}$ Tris- $\mathrm{HCl}$ (pH 9.0), 0.1\% Triton X-100, $1 \mathrm{~mm}$ dNTPs, $1.5 \mathrm{~mm} \mathrm{MgCl}_{2}, 1.5$ units of Taq polymerase, and DEPC-treated $\mathrm{H}_{2} \mathrm{O}$ up to a final volume of $50 \mu$ l. After mineral oil overlay, the tubes were placed on the thermocycler block once it reached $65^{\circ} \mathrm{C}$ 
TABLE 1 Oligonucleotide Sequences for $b c r-a b l$ RT-PCR

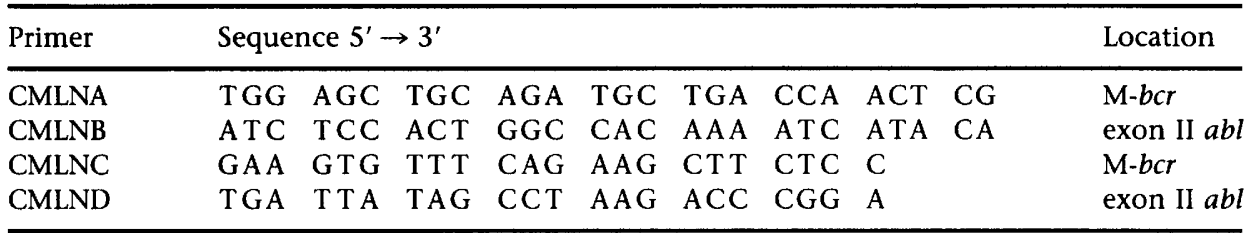

to minimize nonspecific annealing occurring at lower temperatures. The samples were denatured at $95^{\circ} \mathrm{C}$ for $5 \mathrm{~min}$, amplified using 40 cycles of $94^{\circ} \mathrm{C}$ for 30 $\mathrm{sec}, 55^{\circ} \mathrm{C}$ for $1 \mathrm{~min}$, and $72^{\circ} \mathrm{C}$ for $1 \mathrm{~min}$, followed by a final elongation at $72^{\circ} \mathrm{C}$ for $7 \mathrm{~min}$. A dilution of $10^{-6} \mu \mathrm{g}$ of $\mathrm{K} 562$ RNA mixed into $1 \mu \mathrm{g}$ of total HL60 RNA and a second tube with water serving as the sample were used as positive and negative controls, respectively. Fifteen microliters of the final amplification product were run on a $2 \%$ ethidiumstained agarose gel and photographed.

\section{Dilution Preparation}

To test the sensitivity of the assay, a dilution series of decreasing numbers of chronic myelogenous leukemia (CML) leukocytes in phosphate-buffered saline (PBS) was prepared. Leukocytes were isolated from the marrow of a patient with CML in chronic phase using a $3 \%$ dextran density gradient and concentrated to $10^{6}$ cells $/ \mathrm{ml}$ for the initial dilution. From this initial stock, serial dilutions were made so that $2 \mu$ l of a dilution added to a reaction tube would contain the desired number of cells to be analyzed (0.01-500 cells). It is important when using this method to keep the amount of diluent to a minimum to ensure efficient lysis of the cells. Reaction tubes with cells were kept on ice for cell lysis.

\section{Colony Preparation}

We also tested this method on individual myeloid and erythroid colonies de- rived from standard clonogenic methylcellulose assays of CML bone marrow mononuclear cells. Individual colonies containing $\sim 50-200$ cells each were plucked from the cultures after 14 days, placed directly into microcentrifuge tubes, and placed on ice in preparation for cell lysis and rapid RT-PCR.

\section{RESULTS}

Figure 2 shows the results of typical leukocyte cell titration and colony experiments. Dilutions containing as few as 10 CML cells showed amplification of the $b c r-a b l$ transcript. In addition, consistent amplification was observed in 10 of 10 replicates each containing $10 \mathrm{CML}$ cells. Samples containing a single cell showed a detection rate of 6 of 10 . The uniformity of intensity of bands shown PCR in our experience; however, wellto-well block variation can affect amplification efficiency. Individual colonies showed strong amplification with no detectable nonspecific amplification. Samples that were frozen and assayed 60 days after lysis showed no obvious difference in amplification from those that were assayed immediately.

\section{DISCUSSION}

Many RNA purification methods are associated with a number of disadvantages, particularly when working with small cell numbers. Perhaps most important is the level of uncertainty that is introduced by the inherent risk of template loss during multiple sample main Figure $2 \mathrm{~A}$ is characteristic of nested

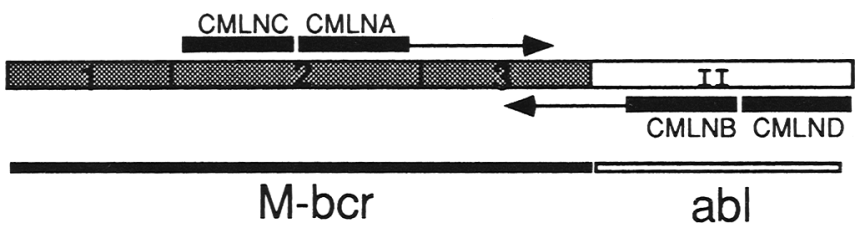

FIGURE 1 Relative positions of primers for detection of $b c r-a b l$ rearrangement. 
plification of RNA when sample material is limited. Total time from beginning of RNA isolation to end of gel electrophoresis is $10 \mathrm{hr}$.

\section{REFERENCES}

1. Chomczynski, P. and N. Sacchi. 1987. Single-step method of RNA isolation by acid guanidinium thiocyanate-phenol-chloroform extraction. Anal. Biochem. 162: 156159.

2. Shi, Y. and L. Liu. 1992. Direct reverse transcription-polymerase chain reaction from whole blood without RNA extraction. Genet. Anal. Techniques Applic. 9: 149-150.

3. Kawasaki, E.S. 1990. PCR protocols: A guide to methods and applications (ed. M.A. Innis, D.H. Gelfan, J.J. Sninsky, and T.J. White), p. 146. Academic Press, San Diego, CA.

Received December 15, 1993; accepted in revised form February 24, 1994. 


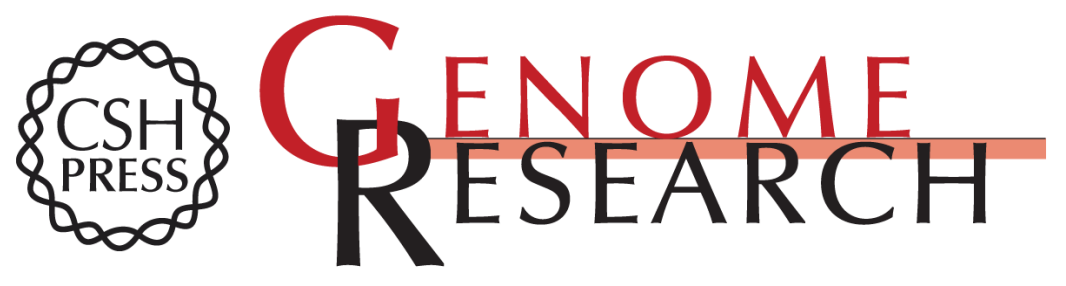

\section{Rapid RT-PCR amplification from limited cell numbers.}

S Edmands, J Kirk, A Lee, et al.

Genome Res. 1994 3: 317-319

\section{License}

Email Alerting Service
Receive free email alerts when new articles cite this article - sign up in the box at the top right corner of the article or click here.

\section{Affordable, Accurate Sequencing.}

To subscribe to Genome Research go to: https://genome.cshlp.org/subscriptions 